\title{
Calculation of Cost of Production Using the Job Order Costing Method Against Determination of Selling Prices at PT OTO Media Kreasi
}

\author{
Alfian Maliki $^{\text {a,1,*, }}$, Heru Satria Rukmana ${ }^{\text {b,2 }}$ \\ ${ }^{\text {a }}$ Program Studi Manajemen, STIE Dewantara, Bogor \\ b Program Studi Manajemen, STIE Dewantara, Bogor \\ 1 rukmanaheru23@yahoo.co.id* \\ * corresponding author
}

\section{ARTICLE INFO}

\section{Article history}

Received

Revised

Accepted

Keywords

Production Cost:

Selling Price;

Job Order Costing Method;

PT Oto Media Kreasi

\begin{abstract}
PT Oto Media Kreasi is a service company engaged in the field of interior and exterior design bodies, producing based on orders or projects. The calculation of the cost of production at PT Oto Media Kreasi plays a role in determining the selling price, which affects the company's profit.

The purpose of this study is to determine the calculation of the cost of production as well calculation in determining the selling price with the method applied by PT Oto Media Kreasi, also to find out the calculation of the cost of production as well as the calculation in determining the selling price using the job order costing method and to know the role of the method job order costing in loading the cost of production precisely and more efficiently.

The results showed that in calculating the cost of production of PT Oto Media Kreasi still used a simple calculation, only calculating the cost of raw materials, namely Rp.1,092,778,291, direct labor costs Rp.313,200,000, and overhead costs Rp.27,600,000. The total calculation of the company's production cost is $R p .1,433,578,291$, with a margin percentage of $35.37 \%$ of the selling price of $R p$. 1,940,640,000. Whereas in calculating the cost of production using the job order costing method in calculating the cost of raw materials Rp.1,101,178,291, the accumulated residual value of raw materials Rp.8,682,000, direct labor costs Rp.313,200,000, and overhead costs Rp.60,532.260. The total calculation of the cost of production using the job order costing method is Rp.1,466,228,551, with a margin percentage of $32.36 \%$ of the selling price of Rp.1,940,640,000. The company has not calculated the cost of goods manufactured using the job order costing method, the cost of goods manufactured is only done by estimating all costs needed to produce a product, so the costs are not classified correctly and the calculations are sufficient simple, so it is difficult to determine the right selling price for a product ordered.

The proposed use of the job order costing method is expected so that the owner of the company can apply the calculation of the cost of production so that the company can determine the cost of production in determining the selling price more precisely, so that the owner can know the overall cost of producing the order and also can know the actual acquisition of margins .
\end{abstract}

\section{PENDAHULUAN}

\section{Latar Belakang}

Tujuan perusahaan mencari keuntungan atau profit untuk memenuhi kebutuhan hidup usahanya semakin meningkat. Agar perusahaan mampu bersaing, perusahaan haruslah memiliki langkah-langkah yang efektif serta efisien dalam mencapai tujuannya yaitu dengan cara meningkatkan mutu produk, meningkatkan efisiensi dan produktivitas kinerja produksi, serta ketepatan dalam menentukan harga jual produknya.

Harga pokok produksi akan menjadi dasar untuk penentuan harga jual di perusahaan. Harga jual sangat erat kaitannya demi pencapaian laba yang dapat diartikan sebagai imbalan atas penghasilan barang atau jasa pada perusahaan (Latief, 2017). Harga jual yang terlalu rendah dapat merugikan perusahaan karena tidak mampu menutup biaya yang dikeluarkan untuk proses produksi dan biaya operasional, namun harga jual yang ditetapkan terlalu tinggi pula akan merugikan perusahaan karena dapat mengurangi kemampuan perusahaan untuk bersaing dengan perusahaan sejenis (Zulkarnain dan Widodo, 2016). 


\section{E ISSN 2715-1212}

Harga pokok produksi berperan sangat penting untuk menilai seluruh sumber ekonomi yang digunakan untuk menentukan harga jual suatu produk sesuai dengan biaya-biaya yang dikeluarkan. Penghitungan harga pokok produksi harus-sesuai dengan pembebanan, sehingga perusahaan dapat membuat kebijakan biaya produksi yang terkait dengan harga jual dengan kompetitif (Windriasari, 2017). Informasi harga pokok pesanan dapat menentukan suatu harga pokok produksi, dengan mengumpulkan biaya produksi pada perusahaan atas dasar pesanan. Manajemen dapat dengan mudah mengambil keputusan tentang harga jual suatu produk dengan hasil yang baik. Harga pokok produksi dalah keseluruhan biaya yang dipergunakan untuk menjalankan kegiatan produksi perusahaan yang dibebankan ke produk maupun jasa perusahaan hasilkan (Fardhani et al, 2016).

Penentuan harga jual yang ideal sebagai perencanaan laba berdasarkan permintaan dan penawaran terkadang sulit dilakukan, yang disebabkan naiknya harga bahan baku beserta tarif dasar listrik dan bahan pendukung lainnya, faktor-faktor tersebut menuntut perusahaan agar menentukan metode yang sesuai dalam penentuan harga pokok produksinya yang pada akhirnya akan mempengaruhi harga jual produk (Aningsih dan Diyani, 2018).

Biaya produksi merupakan biaya-biaya yang terjadi dalam proses harga pokok produk sampai produk tersebut siap di jual. Unsur elemen-elemen yang bersangkutan dalam penghitungan harga pokok produk adalah biaya bahan baku, biaya tenaga kerja, dan biaya overhead. Biaya-biaya produksi yang dikeluarkan dapat di atur dengan seefisien mungkin tanpa menurunkan kepuasan konsumen. Job Order Costing adalah pesanan penjualan dari pelanggan atau pembeli yang akan mengelola produk melalui dokumen pesanan dengan tanggal pesanan yang diterima dan diserahkan jenis, spesifikasi pesanan dan jumlah produk yang di pesan (Hermanto, 2016).

Terdapat dua metode harga pokok produksi yaitu metode job order costing penghitungan harga pokok pesanan merupakan biaya produksi yang diakumulasi untuk setiap pesanan yang terpisah, dan menghasilkan produksi yang berbeda untuk setiap pesanan setiap periode. Perusahaan menentukan biaya berdasarkan pesanan, setiap pesanan harus dapat diidentifikasi secara terpisah dan terlihat secara terperinci dalam kartu biaya pesanan untuk masing-masing pesanan di buat secara teliti dan akurat (Bustami dan Nurlela, 2013). Metode harga pokok proses yaitu process costing yaitu penghitungan berdasarkan proses sesuai yang digunakan. Harga pokok produk dikumpulkan untuk setiap waktu tertentu (Dewi et al, 2017).

Perusahaan memerlukan metode yang tepat serta akurat, untuk menghindari kesalahan dalam penghitungan harga pokok produksi dan untuk menghasilkan harga jual yang baik untuk manajemen dan perusahaan (Yuliyanti dan Saputra, 2017). Perusahaan harus mengatur strategi untuk memberikan kepuasan pada konsumen dengan harga yang sesuai dengan kualitas produk suatu barang, dan harga jual yang tepat (Faridah and Kuswara, 2017). Bagi perusahaan yang menerapkan job order costing, ketepatan penghitungan harga pokok produksi sangatlah penting karena apabila perusahaan tersebut menerima order dari pelanggan, maka perusahaan harus memastikan harga jual produknya sebelum orderan dikerjakan agar perusahaan tidak merugi (Fardhani et al, 2016).

Ibu Louis Nopiyanti selaku pemilik dan presiden direktur, memperluas pasarnya di bidang industri karoseri desain interior dan eksterior kendaraan-dengan cara membangun relasi bersama dealer Mercedes Benz, dealer Toyota dan dealer-dealer lainnya yang memiliki database pembeli mobil serta mengikuti tender dari berbagai klien untuk tujuan komersial, kini PT Oto Media Kreasi telah menyebar mulai dari sektor komersial hingga sektor pemerintah dengan memberikan layanan yang terbaik kepada pelanggannya. Perusahaan ini menelusuri proses pengolahan produk dari bahan baku ke dalam proses produksi, hingga barang setengah jadi dan sampai dihasilkannya produk jadi, PT Oto Media Kreasi adalah perusahaan yang bekerja berdasarkan pesanan atau proyek.

Penghitungan harga pokok produksi pada PT Oto Media Kreasi berfungsi sebagai acuan dalam penentuan harga jual. Dari penghitungan tersebut, sangat berpengaruh terhadap perolehan laba perusahaan. Harga pokok produksi yang di buat dengan metode perusahaan PT Oto Media Kreasi menggunakan variable costing, yang terdiri dari biaya bahan baku, biaya tenaga kerja langsung dan biaya overhead. Selanjutnya, PT Oto Media Kreasi menentukan margin sesuai keinginan untuk memperoleh harga jual.

Biaya bahan baku yang dimasukkan ke dalam harga pokok produksi hanya biaya bahan baku dan biaya bahan pendukung (subcond) saja, perusahaan tidak memasukkan harga perolehan bahan baku tersebut. Biaya tenaga kerja langsung yang dimasukkan PT Oto Media Kreasi ke dalam penghitungan harga pokok

Alfian Maliki, et.al (Calculation of Cost of Production Using the Job Order Costing Method ...) 
produksi adalah biaya pekerja yang di hitung berdasarkan time line pengerjaannya. Biaya overhead yang dimasukkan PT Oto Media Kreasi ke dalam per-hitungan harga pokok produksi hanya biaya air dan listrik, biaya telepon dan internet, dan biaya lainnya.

Biaya yang belum dimasukkan ke dalam penghitungan harga pokok produksi pada PT Oto Media Kreasi meliputi biaya perolehan barang, biaya tenaga kerja tidak langsung, biaya perawatan peralatan dan mesin, biaya perawatan kendaraan dan gedung, biaya akumulasi penyusutan kendaraan dan gedung, serta biaya akumulasi penyusutan mesin dan peralatan. Pentingnya analisis tersebut, maka pembahasan ini mengambil objek penelitian di perusahaan PT. Oto Media Kreasi, karena proses produksi pada perusahaan tersebut berdasarkan pesanan dari konsumen.

Manajemen yang menjalankan suatu proyek di PT Oto Media Kreasi akan menentukan harga pokok produksi sebagai penentuan penawaran harga pesanan konsumen dengan menghitung harga pokok pesanan agar ketepatan biaya dapat diandalkan. Pemesanan atau proyek yang menjadi objek penelitian yaitu Interior Mercedes Benz Sprinter A3, dengan total proyek sebanyak 12 unit dengan harga satuan Rp.161.720.000 per unit belum termasuk pajak, dengan total nilai kontrak Rp.1.940.640.000.

Tabel 1 Data Biaya Harga Pokok Produksi PT Oto Media Kreasi

Proyek 12 Unit Interior Mercedes Benz Sprinter A3 SPK No: OTO 025/MKT/VII/2019

\begin{tabular}{lrr}
\hline KETERANGAN & HARGA/ Unit & JUMLAH/ 12 Unit \\
\hline Biaya Bahan Baku & 91.064 .858 & 1.092 .778 .296 \\
Biaya Tenaga Kerja & 26.100 .000 & 313.200 .000 \\
Biaya Overhead & 2.300 .000 & 27.600 .000 \\
\hline Total HPP & $\mathbf{1 1 9 . 4 6 4 . 8 5 8}$ & $\mathbf{1 . 4 3 3 . 5 7 8 . 2 9 6}$ \\
Margin 35,37\% & 42.255 .142 & 507.061 .704 \\
\hline Harga Jual & $\mathbf{1 6 1 . 7 2 0 . 0 0 0 , -}$ & $\mathbf{1 . 9 4 0 . 6 4 0 . 0 0 0 , -}$ \\
\hline
\end{tabular}

Sumber: Data PPIC PT Oto Media Kreasi, 2018

Pada tabel 1. data biaya harga pokok produksi PT Oto Media Kreasi pada proyek 12 unit interior Mercedes Benz Sprinter A3 di dapat dari staff PPIC (Plan Project Inventory Control) yang di buat pada saat proses penawaran berlangsung.

Berdasarkan uraian tersebut, judul penelitian ini adalah "Penghitungan Harga Pokok Produksi Dengan Metode Job Order Costing Terhadap Penentuan Harga Jual Pada PT Oto Media Kreasi".

\section{Tujuan Penelitian}

Penelitian ini bertujuan:

1. Untuk mengetahui penghitungan harga pokok produksi serta penghitungan dalam menentukan harga jual dengan metode yang diterapkan oleh perusahaan.

2. Untuk mengetahui penghitungan harga pokok produksi serta penghitungan dalam menentukan harga jual dengan metode job order costing.

3. Untuk mengetahui peran metode job order costing dalam pembebanan biaya produksi secara tepat dan lebih efisien.

\section{KAJIAN LITERATUR}

\section{Pengertian Dan Tujuan Akuntansi Biaya}

Akuntansi biaya merupakan bagian yang tidak dapat dipisahkan dari akuntansi manajemen, dan akuntansi keuangan. Dimana pada akuntansi manajeman, akuntansi biaya berperan sebagai penyedia 
informasi yang berguna untuk pengambilan keputusan. Sedangkan bagi akuntansi keuangan, akuntansi biaya berperan sebagai pemyedia informasi untuk penyusunan laporan keuangan.

Menurut Mulyadi (2018:7), akuntansi biaya adalah proses pencatatan, penggolongan, peringkasan dan penyajian biaya, pembuatan dan penjualan produk atau jasa, dengan cara-cara tertentu, serta penafsiran terhadapnya. Objek kegiatan akuntansi biaya adalah biaya.

Proses akuntansi biaya dapat ditujukan untuk memenuhi kebutuhan pemakai luar perusahaan, dengan demikian akuntansi biaya dapat merupakan bagian dari akuntansi keuangan. Proses akuntansi biaya dapat ditujukan untuk memenuhi kebutuhan pemakai dalam perusahaan, dengan demikian akuntansi biaya dapat merupakan bagian dari akuntansi manajemen.

Sedangkan tujuan akuntansi biaya adalah menyediakan salah satu informasi yang diperlukan oleh manajemen dalam mengelola perusahaan. Menurut Mulyadi (2018:7), akuntansi biaya mempunyai tiga tujuan pokok yaitu:

a. Untuk memenuhi tujuan penentuan harga pokok produk, akuntansi biaya mencatat, menggolongkan, dan meringkas biaya-biaya pem-buatan produk atau penyerahan jasa. Biaya yang dikumpulkan dan disajikan adalah biaya yang terjadi di masa lalu atau biaya historis.

b. Pengendalian biaya harus di dahului dengan penentuan biaya yang seharusnya di keluarkan untuk memproduksi satu satuan produk. Jika biaya yang seharusnya ini telah ditetapkan, akuntansi biaya bertugas untuk memantau apakah pengeluaran biaya yang sesungguhnya sesuai dengan biaya yang seharusnya tersebut.

c. Pengambilan keputusan khusus menyangkut masa yang akan datang. Oleh karena itu informasi yang relevan dengan pengambilan keputusan khusus selalu berhubungan dengan informasi masa yang akan datang. Informasi biaya ini tidak dicatat dalam catatan akuntansi biaya, melainkan hasil dari suatu proses peramalan.

\section{Pengertian Dan Penggolongan Biaya}

Pengertian biaya menurut Mulyadi (2018:8) Biaya adalah pengorbanan sumber ekonomis yang diukur dalam satuan uang, yang telah terjadi, sedang terjadi atau yang kemungkinan akan terjadi untuk tujuan tertentu. Sedangkan pengertian biaya menurut Siregar dkk (2014:23) yaitu Cost adalah pengorbanan sumber ekonomi untuk memperoleh barang atau jasa yang diharapkan memberikan manfaat sekarang atau masa yang akan datang.

Biaya (cost) belum habis masa pakainya, dan digolongkan sebagai aktiva yang dimasukkan ke dalam neraca. Biaya ini adalah biaya yang belum dinikmati dan dapat memberikan manfaat di masa yang akan datang selanjut-nya dikelompokkan sebagai harta. Beban (Expense) dimasukkan ke dalam laba rugi, sebagai pengurang pendapatan.

Menurut Mulyadi (2018), menjelaskan bahwa biaya dapat digolongkan menurut:

1. Objek Pengeluaran

2. Fungsi pokok dalam perusahaan

3. Hubungan biaya dengan sesuatu yang dibiayai

4. Perilaku biaya dalam hubungannya dengan perubahaan volume kegiatan

5. Jangka waktu manfaatnya

\section{Harga Pokok Produksi}

Menurut Bustami dan Nurlela (2013:49) harga pokok produksi adalah kumpulan biaya produksi yang terdiri dari bahan baku langsung, tenaga kerja langsung, dan biaya overhead yang di tambah dengan persediaan barang dalam proses awal dan dikurangi persediaan barang dalam proses akhir.

Menurut Hansen dan Mowen (2009:60) mengemukakan harga pokok produksi adalah total seluruh biaya-biaya yang digunakan dalam membuat atau memproduksi suatu barang. Biaya yang di pakai untuk produksi barang di hitung perusahaan secara teliti agar dapat menentukan harga pokok produksi yang akurat.

Menurut Mulyadi (2018:17) metode pengumpulan harga pokok produksi sangat ditentukan oleh cara produksi. Untuk memproduksi suatu produk, di bagi menjadi dua metode yaitu:

\section{Biaya Berdasarkan Proses (Proccess Costing)}


Metode ini digunakan oleh perusahaan yang berproduksi secara terus menerus untuk persediaan gudang atau perusahaan yang tidak membuat barang produksi berdasarkan pesanan.

2. Biaya Berdasarkan Pesanan (Job Order Costing)

Metode ini digunakan oleh perusahaan yang memproduksi barang berdasarkan pesanan atau sesuai dengan keinginan konsumen. Biasanya perusahaan yang menggunakan metode ini memproduksi barang terputus-putus sesuai dengan pesanan yang masuk.

Metode penentuan harga pokok produksi yaitu suatu cara untuk memperhitungkan unsur-unsur biaya ke dalam harga pokok produk. Terdapat dua pendekatan dalam penghitungan harga pokok produk:

1. Biaya Penuh (Full Costing)

Menurut Mulyadi (2018:17), harga pokok produksi yaitu memper-hitungkan semua unsur biaya produksi ke dalam harga pokok produksi, yang terdiri dari biaya bahan baku, biaya tenaga kerja langsung, dan biaya overhead pabrik, baik yang berperilaku variabel maupun tetap. Dengan demikian kos produksi menurut metode full costing terdiri dari unsur biaya berikut ini:

Tabel 2.1. Full Costing

\begin{tabular}{lc}
\hline Biaya bahan baku & $\mathrm{xxx}$ \\
Biaya tenaga kerja langsung & $\mathrm{xxx}$ \\
Biaya overhead pabrik variabel & $\mathrm{xxx}$ \\
Biaya overhead pabrik tetap & $\mathrm{xxx}$ \\
Harga pokok produksi & $\mathrm{xxx}$ \\
\hline
\end{tabular}

Sumber: Mulyadi (2018:18)

2. Biaya Variabel (Variable Costing)

Menurut Mulyadi (2018:18), Variable Costing merupakan metode penentuan harga pokok produksi yang hanya memperhitungkan biaya produksi yang berperilaku variabel ke dalam kos produksi, yang terdiri dari biaya bahan baku, biaya tenaga kerja langsung, dan biaya overhead variabel. Dengan demikian kos produksi menurut metode variable costing terdiri dari unsur biaya produksi berikut ini:

Tabel 2.2. Variable Costing

\begin{tabular}{lc}
\hline Biaya bahan baku & $\mathrm{xxx}$ \\
Biaya tenaga kerja langsung & $\mathrm{xxx}$ \\
Biaya overhead pabrik variabel & $\mathrm{xxx}$ \\
\hline Harga pokok produksi & $\mathbf{x x x}$ \\
\hline
\end{tabular}

Sumber: Mulyadi (2018:19)

Sistem penghitungan biaya produksi dalam suatu perusahaan dipengaruhi oleh karakteristik proses produksi perusahaan tersebut. Dalam sistem penghitungan biaya berdasarkan pesanan, biaya produksi diakumulasikan untuk setiap pesanan. Hal ini dimaksudkan agar rincian biaya berdasarkan pesanan sesuai dengan upaya yang diperlukan dalam memenuhi pesanan ini, dan untuk itu perlu adanya pembedaan penting atas biaya per unit suatu pesanan dengan pesanan yang lain. Rincian biaya dalam setiap pesanan tersebut di catat dalam kartu biaya pesanan yang nantinya berfungsi sebagai buku pembantu. Agus Purwaji, dkk (2016:72). 
Job Order Costing adalah cara penghitungan harga pokok produksi untuk produk yang di buat berdasarkan pesanan. Apabila suatu pesanan di terima segera dikeluarkan perintah untuk membuat produk sesuai dengan spesifikasi masing-masing pesanan. Untuk mempermudah penghitungan biaya produksi tiaptiap pesanan, maka masing-masing produk yang dikerjakan di beri nomor identitas.

Ciri Khusus Job Order Costing

a. Tujuan produksi perusahaan adalah untuk melayani pesanan pembeli yang bentuknya tergantung pada spesifikasi pesanan, sehingga sifat produksinya terputus-putus dan setiap pesanan dapat dipisahkan identi-tasnya secara jelas.

b. Biaya produksi dikumpulkan untuk setiap pesanan dengan tujuan dapat di hitung harga pokok pesanan dengan relatif teliti dan adil. Dihubungkan dengan sistem akuntansi biaya yang digunakan untuk membebankan harga pokok kepada produk. metode harga pokok pesanan hanya dapat menggunakan:

Job Order Costing Dalam Pencatatan Akuntansi

a. Akuntansi biaya bahan baku

Pencatatan pemakaian bahan baku didasarkan pada bukti permintaan bahan (material reguisition). Di samping di catat pada kartu persediaan bahan baku, pemakaian tersebut juga harus di catat di kartu harga pokok pesanan yang bersangkutan.

\begin{tabular}{|c|c|c|}
\hline \multicolumn{3}{|l|}{ Pada saat pembelian: } \\
\hline & Persediaan bahan baku & $\mathrm{xxx}$ \\
\hline & Utang/kas & $\mathrm{xxx}$ \\
\hline \multicolumn{3}{|c|}{ Pada saat terjadi retur Pembelian: } \\
\hline & Utang & $\mathrm{xxx}$ \\
\hline & Persediaan bahan baku & $\mathrm{xxx}$ \\
\hline \multicolumn{3}{|c|}{ Pada saat pembebanan: } \\
\hline & BDP - Biaya bahan baku & $\mathrm{xxx}$ \\
\hline & Persediaan bahan baku & $\mathrm{xxx}$ \\
\hline
\end{tabular}

b. Akuntansi biaya tenaga kerja

Pembebanan upah langsung ke barang dalam proses, harus di catat pada kartu harga pokok pesanan sesuai dengan pemakaian tenaga kerja yang bersangkutan.

Pada saat pembayaran karyawan:

$\begin{array}{ll}\text { Utang gaji dan upah } & \text { xxx } \\ \text { Kas } & \text { xxx }\end{array}$

Pada saat pembebanan:

BDP - Biaya tenaga kerja $\quad$ xxx

Gaji dan upah $\quad$ xxx

c. Akuntansi biaya overhead pabrik 
Dalam harga pokok pesanan biaya overhead pabrik dibebankan berdasarkan tarif yang ditentukan sebelum proses produksi berjalan (predetermined rate).

Adapun proses penentuan tarif adalah sebagai berikut:

1) Menentukan taksiran besarnya BOP selama periode tertentu.

2) Menentukan dasar pembebanan (jam kerja langsung, jam kerja mesin, dll).

3) Menentukan tarif BOP berdasarkan:

\begin{tabular}{|c|c|c|}
\hline \multirow{2}{*}{ Tarif $\mathrm{BOP}=$} & Taksiran BOP $=R p \ldots . D$ & \multirow{2}{*}{$=$ Rp.../Dasar pembebanan } \\
\hline & Dasar pembebanan & \\
\hline \multicolumn{3}{|c|}{ Pada saat pembebanan: } \\
\hline & $\begin{array}{l}\text { BDP - Biaya Overhead } \\
\text { BOP yang dibebankan }\end{array}$ & $\begin{array}{ll}\mathrm{xxx} \\
\mathrm{xxx}\end{array}$ \\
\hline \multicolumn{3}{|c|}{ Mencatat BOP Sesungguhnya: } \\
\hline & $\begin{array}{l}\text { BOP yang sesungguhnya } \\
\text { Berbagai rekening di kredit }\end{array}$ & $\mathrm{xxx}_{\mathrm{xxx}}$ \\
\hline
\end{tabular}

d. Pencatatan Barang Jadi

Pencatatan barang jadi didasarkan kepada pesanan-pesanan yang telah selesai, dengan demikian harga pokok barang jadi didasarkan kepada harga pokok tiap pesanan yang telah selesai dikerjakan, sehingga besarnya harga pokok tersebut dapat di lihat pada kartu harga pokok

\begin{tabular}{lc}
\hline Persediaan barang jadi & $\mathrm{xxx}$ \\
BDP - Biaya bahan baku & $\mathrm{xxx}$ \\
BDP - Biaya tenaga kerja & $\mathrm{xxx}$ \\
BDP - Biaya overhead pabrik & $\mathrm{xxx}$ \\
\hline
\end{tabular}

e. Pencatatan Persediaan Barang Dalam Proses

\begin{tabular}{lc}
\hline Persediaan barang dalam proses & $\mathrm{xxx}$ \\
& \\
BDP - Biaya bahan baku & $\mathrm{xxx}$ \\
BDP - Biaya tenaga kerja & $\mathrm{xxx}$ \\
BDP - Biaya overhead pabrik & $\mathrm{xxx}$ \\
\hline
\end{tabular}

f. Pencatatan Penyerahan Barang Kepada Pemesan

\begin{tabular}{cl}
\hline Piutang & $\mathrm{xxx}$ \\
Penjualan & $\mathrm{xxx}$ \\
\hline
\end{tabular}




\section{E ISSN 2715-1212}

g. Pencatatan Harga Pokok Penjualan

\begin{tabular}{ll}
\hline $\begin{array}{l}\text { Harga pokok penjualan } \\
\text { Persediaan barang jadi }\end{array}$ & $\mathrm{xxx}$ \\
& $\mathrm{xxx}$ \\
\hline
\end{tabular}

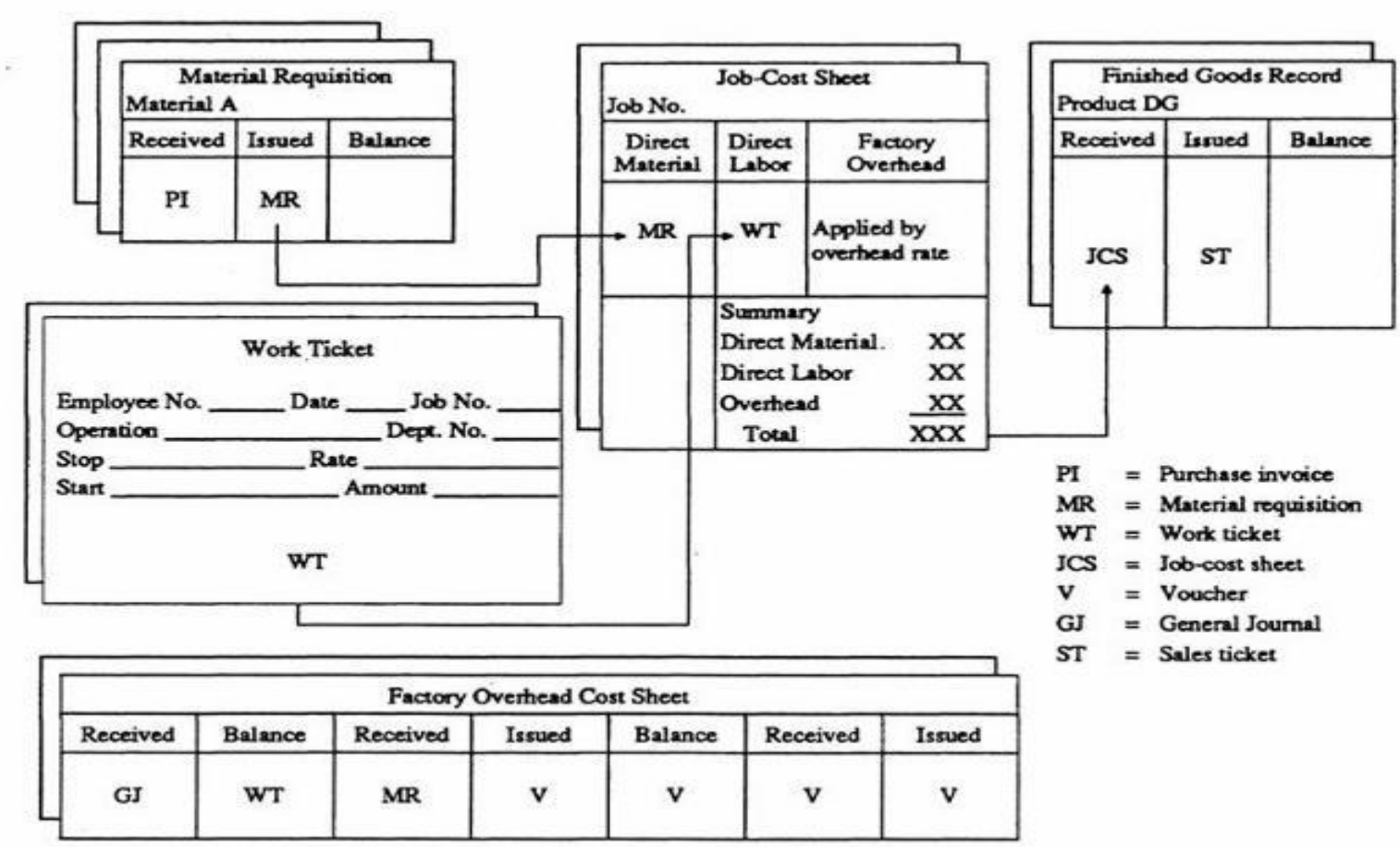

Sumber: Zola Permatasari (2011)

Gambar 1 Job Order Costing Illustration

\section{Harga Jual}

Menurut Kotler dan Keller (Sujarweni, 2015:72) menyatakan bahwa harga jual adalah sejumlah uang yang dibebankan atas suatu produk atas jasa, atas jumlah nilai yang di tukar konsumen atas manfaat-manfaat, karena memiliki atau menggunakan produk atau jasa tersebut.

Harga merupakan satu hal penting, dimana harga merupakan komponen besar dari kepuasan konsumen, dan nilai produk adalah apa yang dirasakan oleh konsumen, jadi pembeli membantu menetapkan nilai dari produk. Dari sudut pandang produsen, harga tentu saja mempunyai peranan yang sangat penting.

Laba yang akan diperoleh perusahaan dan kelangsungan hidup perusahaan sangat ditentukan oleh seberapa besar pendapatan yang di-peroleh, dan ini tergantung dari berapa banyaknya jumlah produk yang terjual.

Banyaknya jumlah penjualan produk sangat dipengaruhi oleh harga jual produk itu sendiri. Jadi harga jual merupakan hal penting atas suatu produk yang di jual baik bagi produsen maupun bagi konsumen.

Pada umumnya, biaya tidak menentukan harga jual produk atau jasa. Harga jual suatu produk terbentuk di pasar sebagai interaksi antara jumlah permintaan dan penawaran di pasar. Manajemen memerlukan informasi-biaya penuh untuk memperhitungkan konsekuensi laba dari setiap alternatif harga jual yang terbentuk di pasar. Oleh karena itu, dalam keadaan normal, manejemen puncak harus memperoleh jaminan bahwa harga jual produk atau jasa yang di jual di pasar dapat menutup biaya penuh untuk menghasilkan produk atau jasa tersebut dan dapat menghasilkan laba yang wajar. 
Harga adalah nilai barang atau jasa yang diungkapkan dalam suatu rupiah atau satuan mata uang lainnya. Jumlah moneter yang dibebankan kepada pembeli atau pelanggan atas produk atau jasa yang telah di jual dimana jumlah moneter yang bebankan berupa biaya produksi, biaya non produksi dan laba.

Tujuan pokok penentuan harga jual adalah sebagai berikut:

a. Mencapai target penjualan (return on investment).

b. Memaksimumkan laba.

c. Meningkatkan penjualan dan mempertahankan atau memperluas pangsa pasar.

d. Menstabilkan harga.

\section{Penentuan Harga Jual}

Penentuan harga oleh manajemen idealnya memastikan pemulihan atas semua biaya dan mencapai laba, dalam kondisi yang sulit sekalipun. Meskipun penawaran dan permintaan biasanya merupakan faktor penentu dalam penetapan harga, penetapan harga jual yang menguntungkan me-merlukan pertimbangan atas biaya.

Kebijakan penentuan harga jual adalah pernyataan sikap manajemen terhadap penentuan harga jual produk atau jasa. Kebijakan tersebut tidak menentukan harga jual, namun menetapkan faktor-faktor yang perlu di per-timbangkan dan aturan dasar yang perlu di ikuti dalam penentuan harga jual.

Keputusan penentuan harga jual adalah penentuan harga jual produk suatu organisasi yang umunya di buat untuk jangka pendek. Keputusan ini dipengaruhi oleh kebijakan penentuan harga jual, pemanfaatan kapasitas dan tujuan organisasi. Keputusan penentuan harga jual biasanya harus di buat berulang-ulang karena harga jual dipengaruhi oleh perubahan lingkungan eksternal dan internal.

Perubahan harga jual bertujuan agar harga jual yang baru dapat mencerminkan biaya saat ini (current cost) atau malahan biaya masa depan (future cost), kondisi pasar, reaksi pesaing, laba atau return yang diinginkan. Dalam jangka panjang, harga jual yang ditentukan harus dapat menghasilkan pendapatan masa depan yang cukup untuk menutup semua biaya masa depan dan laba atau return masa depan yang diinginkan.

Umumnya keputusan harga jual produk dan jasa standar ditentukan oleh pertimbangan permintaan dan penawaran di pasar, sehingga biaya bukan merupakan penentuan harga jual. Karena permintaan customer atas produk dan jasa tidak mudah ditentukan oleh manajer penentu harga jual, maka dalam penentuan harga jual, manajer tersebut akan menghadapi banyak ketidakpastian.

Selera customer, jumlah pesaing yang memasuki pasar, dan harga jual yang ditentukan oleh pesaing, merupakan contoh faktor yang sulit untuk diramalkan, yang mempengaruhi pembentukan harga jual produk atau jasa di pasar. Banyak faktor yang mempengaruhi penentuan harga jual selain biaya dari pembuatan produk itu sendiri. Harga jual ini harus disesuaikan dengan jenis perusahaan, produk dan pasarnya.

\section{Kajian Penelitian Terdahulu}

Tabel 4 Kajian Penelitian Terdahulu

\begin{tabular}{|c|c|c|c|c|}
\hline No & Nama & Judul & Metode & Hasil \\
\hline 1. & $\begin{array}{l}\text { Dini Catur } \\
\text { Wulandari, } \\
2017 \\
\text { Universitas } \\
\text { Dian } \\
\text { Nuswantoro, } \\
\text { Semarang }\end{array}$ & $\begin{array}{l}\text { Penggunaan } \\
\text { Metode Job } \\
\text { Order Costing } \\
\text { Dalam } \\
\text { Menentukan } \\
\text { Harga Pokok } \\
\text { Produksi Untuk } \\
\text { Meningkatkan } \\
\text { Harga Jual } \\
\text { Pada }\end{array}$ & $\begin{array}{l}\text { Job } \\
\text { Order } \\
\text { Costing }\end{array}$ & $\begin{array}{l}\text { 1. Terdapat perbedaan dalam } \\
\text { penghitungan hpp. } \\
\text { 2. Penghitungan hpp lebih akurat } \\
\text { dengan metode job order costing. } \\
\text { 3. Menambah akun biaya penyusutan } \\
\text { dan biaya pemeliharaan } \\
\text { 4. Terdapat kesalahan dalam } \\
\text { penghitungan dan pengelompokkan } \\
\text { biaya produksi dan biaya non } \\
\text { produksi. }\end{array}$ \\
\hline
\end{tabular}




$$
\begin{array}{ll}
\text { Perusahaan } & \text { 5. Adanya usulan penggunaan } \\
\text { Mebel } & \text { metode job order costing untuk } \\
& \text { perusahaan. }
\end{array}
$$

\begin{tabular}{|c|c|c|c|c|}
\hline 2. & $\begin{array}{l}\text { Riska Putri } \\
\text { Sekar } \\
\text { Tanjung } \\
\text { Sari, } 2016 \\
\text { Universitas } \\
\text { Sanata } \\
\text { Dharma, } \\
\text { Yogyakarta }\end{array}$ & $\begin{array}{l}\text { Analisis } \\
\text { Penghitungan } \\
\text { Harga Pokok } \\
\text { Produksi } \\
\text { Dengan Metode } \\
\text { Job Order } \\
\text { Costing }\end{array}$ & $\begin{array}{l}\text { Job } \\
\text { Order } \\
\text { Costing }\end{array}$ & $\begin{array}{l}\text { Penghitungan HPP sesuai dengan } \\
\text { metode job order costing dengan } \\
\text { sedikit selisih perbedaan pada biaya } \\
\text { overhead pabrik. }\end{array}$ \\
\hline 3. & $\begin{array}{l}\text { Aan Invado, } \\
2018 \\
\text { Universitas } \\
\text { Islam Negri } \\
\text { Maulana } \\
\text { Malik } \\
\text { Ibrahim, } \\
\text { Malang }\end{array}$ & $\begin{array}{l}\text { Implementasi } \\
\text { Metode Job } \\
\text { Order Costing } \\
\text { Pada Harga } \\
\text { Jual di Batik } \\
\text { Celakat Malang }\end{array}$ & $\begin{array}{l}\text { Job } \\
\text { Order } \\
\text { Costing }\end{array}$ & $\begin{array}{l}\text { 1. Belum menghitung HPP sebelum } \\
\text { menentukan harga jual. } \\
\text { 2. (Hasil penghitungan berdasarkan } \\
\text { pengamatan dilapangan). } \\
\text { 3. (Hasil analisis penghitungan HPP } \\
\text { dengan metode job order costing } \\
\text { sebagai penentuan harga jual } \\
\text { dengan kebijakan margin). }\end{array}$ \\
\hline
\end{tabular}

Sumber: Data diolah

\section{Definisi Operasional}

Tabel 5. Definisi Operasional

\begin{tabular}{llll}
\hline No & Variabel & Definisi Variabel & Indikator \\
\hline 1. & Biaya produksi & Biaya produksi atau harga pokok & a. Biaya bahan baku \\
berdasarkan & produksi merupakan kumpulan & b. Biaya tenaga kerja \\
pesanan & dari biaya-biaya yang dikeluarkan & c. Biaya Overhead \\
& untuk memperoleh dan mengolah & \\
& bahan baku menjadi barang jadi & \\
& berdasarkan pesanan. &
\end{tabular}

Sumber: Data diolah 


\section{Kerangka Pemikiran}

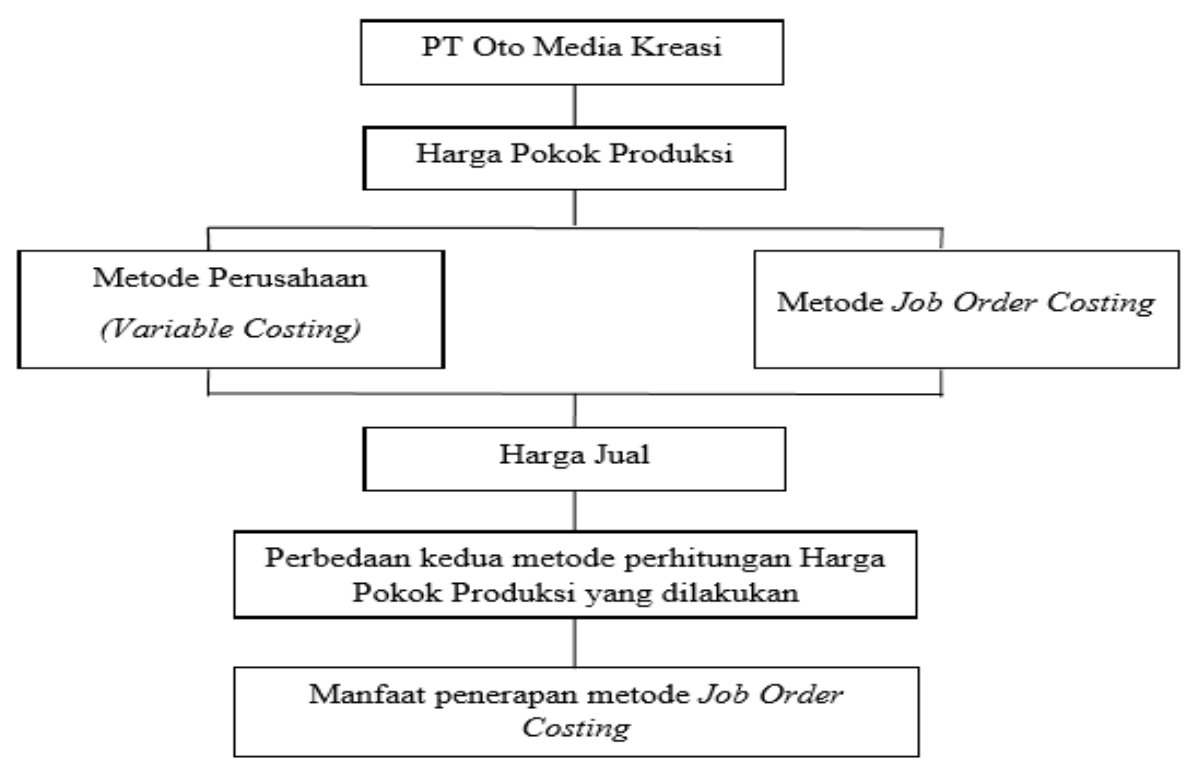

Sumber. Data diolah

Gambar 2. Kerangka Pemikiran

\section{METODOLOGI PENELITIAN}

\section{Jenis Penelitian}

Jenis penelitian yang digunakan dalam penelitian ini adalah deskriptif dan komparatif dengan pendekatan kuantitatif. Data yang di peroleh dengan survei lapangan atau observasi di perusahaan PT Oto Media Kreasi. Dalam penelitian ini yang menjadi variabel bebas adalah harga pokok produksi. Adapun yang menjadi variabel terikat dalam penelitian ini adalah harga jual.

\section{Lokasi Dan Waktu Penelitian}

Tempat penelitian yang di pilih adalah PT. Oto Media Kreasi yang beralamat di Jl. RE Martadinata Ciputat No. 43, Tangerang Selatan-Banten. Penelitian ini di mulai pada bulan Oktober sampai dengan Desember 2019.

\section{Objek Penelitian}

PT. Oto Media Kreasi adalah perusahaan yang bergerak di bidang jasa karoseri interior dan eksterior kendaraan yang didirikan pada tanggal 14 Desember 2017. Atas izin dan dari pemilik perusahaan ini untuk memberikan informasi terkait dengan penghitungan harga pokok produksi terhadap penentuan harga jual pada PT Oto Media Kreasi yang dibutuhkan dalam melakukan penelitian, maka dari itu jadikan sebagai objek penelitian.

\section{Populasi Dan Sampel}

Populasi pada penelitian ini adalah data perusahaan terkait dengan data penjualan pada PT Oto Media Kreasi. Sedangkan sampel yang digunakan dalam penelitian ini adalah harga pokok produksi produk jasa interior mobil Proyek 12 Unit Interior Mercedes Benz Sprinter A3, SPK No: OTO-025/MKT/VII/2019.

\section{Teknik Pengumpulan Data}

Penelitian ini menggunakan data primer dan data sekunder. Adapun data primer di peroleh langsung dari objek yang diteliti berupa hasil wawancara dengan pimpinan produksi dan PPIC (Plan Project Inventory and Control) PT Oto Media Kreasi yang memahami dalam penghitungan harga pokok produksi dan dianggap paling memiliki pemahaman terhadap permasalahan yang di teliti mengenai data yang diperlukan dalam penelitian ini. 
Adapun data yang diperlukan yaitu berupa laporan biaya-biaya produksi seperti biaya bahan baku, biaya tenaga kerja dan biaya overhead perusahaan. Sedangkan data sekunder merupakan data yang di peroleh dari media perantara seperti buku, SPK, penawaran harga No: 025/PT.OMK/IX/2018, invoice No: 025-1/PT.OMK/IV/2019, dan media lain yang mendukung penelitian ini.

\section{Teknik Analisis Data}

Teknik analisis data yang digunakan adalah metode analisis deskriptif. Menurut Sugiyono (2014:21), metode analisis deskriptif yaitu statistik yang digunakan untuk menganalisa data dengan cara mendeskripsikan atau menggambarkan data yang telah terkumpul sebagaimana adanya tanpa bermaksud membuat kesimpulan yang berlaku untuk umum atau generalisasi. Analisis deskriptif merupakan cara merumuskan dan menafsirkan data yang ada sehingga memberikan gambaran yang jelas melalui pengumpulan, penyusunan dan menganalisa data, sehingga dapat diketahui gambaran umum tentang kegiatan produksi perusahaan. Penelitian ini dilakukan untuk mengetahui dan menjelaskan karakteristik variabel yang diteliti dalam suatu situasi. Urutan data yang digunakan meliputi pengumpulan data, pemilihan data dan analisis data, dan kemudian melakukan simulasi penghitungan untuk membuat kesimpulan dan saran.

Langkah-langkah analisis yang dilakukan dalam penelitian ini adalah sebagai berikut:

1. Pengumpulan data, yaitu dengan mengumpulkan semua data-data yang terlibat dalam proses produksi seperti biaya bahan baku, biaya tenaga kerja langsung dan biaya overhead yang dibutuhkan untuk proses penelitian.

2. Pemilihan data, setelah data-data biaya produksi telah dikumpulkan kemudian data di pilih dan diklasifikasikan sesuai klasifikasi biaya.

3. Analisis data, setelah data dikumpulkan dan di pilih atau diklasifikasikan sesuai kelompok biaya masingmasing kemudian penulis menganalis seluruh data yang telah ada untuk kemudian penulis menganalisis seluruh data yang telah ada untuk kemudian dikelompokkan sesuai kebutuhan penulis untuk melakukan penghitungan harga pokok produksi dari masing-masing barang yang di produksi.

4. Simulasi penghitungan, setelah dilakukan analisis data kemudian akan dilakukan simulasi penghitungan harga pokok produksi dan penentuan harga jual yang dilakukan perusahaan dan simulasi penghitungan dengan metode Job Order Costing untuk menentukan perbedaan yang kemudian akan di analisis untuk membuat kesimpulan sejauh mana metode Job Order Costing berperan penting dalam kegiatan produksi perusahaan.

Berikut adalah format penghitungan untuk menghitung biaya produksi pesanan menurut Mulyadi (2018: 39-41):

1. Menentukan harga jual yang akan dibebankan kepada pemesan, dengan format berikut:

Taksiran biaya produksi untuk pesanan

XXX

Taksiran biaya non produksi dibebankan kepada pesanan

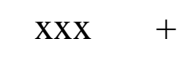

Taksiran total biaya produksi pesanan

Laba yang diinginkan

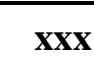

XXX +

Taksiran harga jual yang dibebankan kepada pemesan

$\mathbf{X X X}$

2. Menaksirkan biaya produksi yang akan dikeluarkan dalam memproduksi pesanan tertentu:

Taksiran biaya bahan baku

XXX

Taksiran biaya tenaga kerja langsung

$\mathrm{xxx}$

Taksiran biaya overhead pabrik

Total biaya produksi 
3. Total harga pokok pesanan di hitung dengan unsur biaya berikut ini:

Biaya produksi pesanan:

Taksiran biaya bahan baku XXX

Taksiran biaya tenaga kerja langsung

Taksiran biaya overhead pabrik XXX +

\section{a. Taksiran biaya produksi}

Biaya non produksi:

Taksiran biaya administrasi dan umum

XXX

Taksiran biaya pemasaran

XXX +

b. Taksiran biaya non produksi

Taksiran total harga pokok pesanan $(a+b)$

$\mathbf{x x x}$

4. Penghitungan biaya produksi pesanan dengan formula sebagai berikut:

Biaya bahan baku sesungguhnya

XXX

Biaya tenaga kerja sesungguhnya

XXX

Taksiran biaya overhead

XXX +

\section{Total biaya produksi sesungguhnya}

$\mathbf{X X X}$

\section{HASIL DAN PEMBAHASAN}

\section{Gambaran Umum Perusahaan}

PT Oto Media Kreasi adalah sebuah perusahaan jasa yang bergerak di bidang karoseri desain interior dan eksterior yang memproduksi berbagai jenis desain atau model interior dan eksterior yang kemudian diimplementasikan pada kendaraan, dibuat sedemikian rupa untuk memenuhi kebutuhan dan keinginan konsumen atau pembeli. PT Oto Media Kreasi didirikan pada tanggal 14 Desember 2017, memulai perjalanan sebagai jasa karoseri interior dan eksterior, dengan merek dagang atau jual yaitu $X$-Buz. PT Oto Media Kreasi merupakan perusahaan yang mengembangkan inovasi, kreatifitas, mengedepankan kualitas produk, serta mengunggulkan teknologi, sehingga menjadikan produk yang dihasilkan sudah terkenal hampir ke seluruh wilayah di kota Tangerang serta luar kota Tangerang. Dengan harga produk yang cukup mahal, namun konsumen tidak pernah mengeluh atas barang yang dihasilkan, karena kualitas yang diinginkan selalu sesuai dengan selera konsumen.

Kualitas menjadi hal yang paling penting dalam memproduksi suatu barang, hal itulah yang menjadi faktor penentu dalam melakukan setiap kegiatan produksi yang dilakukan oleh perusahaan. Berbeda dengankebanyakan usaha yang sejenis, PT Oto Media Kreasi merupakan perusahaan yang merealisasikan produk berdasarkan keinginan konsumen. Perusahaan selalu menggunakan bahan baku yang berkualitas tinggi serta ramah lingkungan. Alasan utama perusahaan dalam memilih bahan baku yang berkualitas yaitu karena perusahaan sangat mengedepankan kualitas produk yang dihasilkan serta untuk memenuhi kepuasan konsumen.

\section{Visi-Misi Usaha}


1. Visi

a. Menjadi perusahaan jasa customized interior and exterior (auto designs), yang mengedepankan kualitas dalam setiap pelayanan.

b. Menjadi perusahaan jasa customized yang handal dan terpercaya.

2. Misi
a. Menyediakan pelayanan yang berkualitas tinggi dan terpercaya.
b. Memberikan keamanan, kenyamanan, kepuasan, serta kemewahan desain interior dan eksterior pada kendaraan.
c. Menjadikan pilihan terbaik di bidang jasa customized interior and exterior (auto designs).

\section{Struktur Organisasi Perusahaan}

Dalam struktur organisasi pada perusahaan PT Oto Media Kreasi terdapat personil atau bagian yang tergolong dalam jajaran inti struktur perusahaan, yaitu Pemilik Usaha atau Direktur Utama. Selanjutnya Marketing dan Finance, HRD (Human Resource Development) dan Purcashing, Kepala-Produksi dan PPIC (Plan Project Inventory and Control), Designer dan Engineering. Dan pada susunan di bawahnya terdapat para pekerja yaitu Operator Produksi dan Helper.

Selain membangun relasi bersama dealer-dealer dan mengikuti tender-tender, PT Oto Media Kreasi pun memasarkan produknya dengan meng-gunakan metode Mouth to Mouth atau yang sering dikenal dengan istilah mulut ke mulut, strategi ini dianggap mampu berdampak baik dari penjualan produk yang dihasilkan, menjanjikan kualitas yang baik di anggap mampu menarik minat konsumen untuk menggunakan jasa PT Oto Media Kreasi. Untuk target pasarnya yaitu seluruh wilayah di Indonesia.

\section{Simulasi Penghitungan HPP Perusahaan}

Berikut ini, penulis menguraikan biaya-biaya yang dibutuhkan dalam melakukan penghitungan harga pokok produksi yang dilakukan perusahaan dengan penghitungan harga pokok produksi dengan metode $J o b$ Order Costing.

Tabel 4. Biaya Bahan Baku Penghitungan Perusahaan (Interior Mercedes Benz Sprinter A3) Tender Proyek 12 Unit

\begin{tabular}{lccc}
\hline \multicolumn{1}{c}{ Nama Bahan } & Qty & Harga @ satuan & Total Biaya \\
\hline $\begin{array}{l}\text { Biaya Bahan Baku } \\
\text { Biaya Bahan Pendukung } \\
\text { (Subcond) }\end{array}$ & 12 Unit & 80.064 .858 & 960.778 .291 \\
\hline & 12 Unit & 11.000 .000 & 132.000 .000 \\
\hline
\end{tabular}

Pada Tabel 4.1. dijelaskan bahwa biaya bahan baku pada penghitungan perusahaan meliputi biaya bahan baku dan biaya bahan pendukung (subcond), dengan total biaya bahan baku sebesar Rp. 1.092.778.291,--

Tabel 4.2. Biaya Tenaga Kerja Langsung Penghitungan Perusahaan (Interior Mercedes Benz Sprinter A3) Tender Proyek 12 Unit

\begin{tabular}{|c|c|c|c|c|c|}
\hline $\begin{array}{c}\text { Jenis } \\
\text { Pekerjaan }\end{array}$ & $\begin{array}{c}\text { Jumlah } \\
\text { Karyawan }\end{array}$ & Gaji /Hari & $\begin{array}{c}\text { Waktu } \\
\text { Penyelesaian }\end{array}$ & \multicolumn{2}{|c|}{$\begin{array}{c}\text { Total Gaji Total Gaji /12 } \\
\text { /Unit Unit } \\
\end{array}$} \\
\hline $\begin{array}{l}\text { Operator } \\
\text { Produksi }\end{array}$ & 7 Orang & 180.000 & 15 Hari & 18.900 .000 & 226.800 .000 \\
\hline Helper & 4 Orang & 120.000 & 15 Hari & 7.200 .000 & 86.400 .000 \\
\hline
\end{tabular}


Pada Tabel 4.2. dijelaskan bahwa biaya tenaga kerja langsung pada penghitungan perusahaan meliputi gaji operator produksi dan helper, dengan total biaya tenaga kerja langsung sebesar Rp. 313.200.000,-.

Tabel 4.3. Biaya Overhead Penghitungan Perusahaan (Interior Mercedes Benz Sprinter A3) Tender Proyek 12 Unit

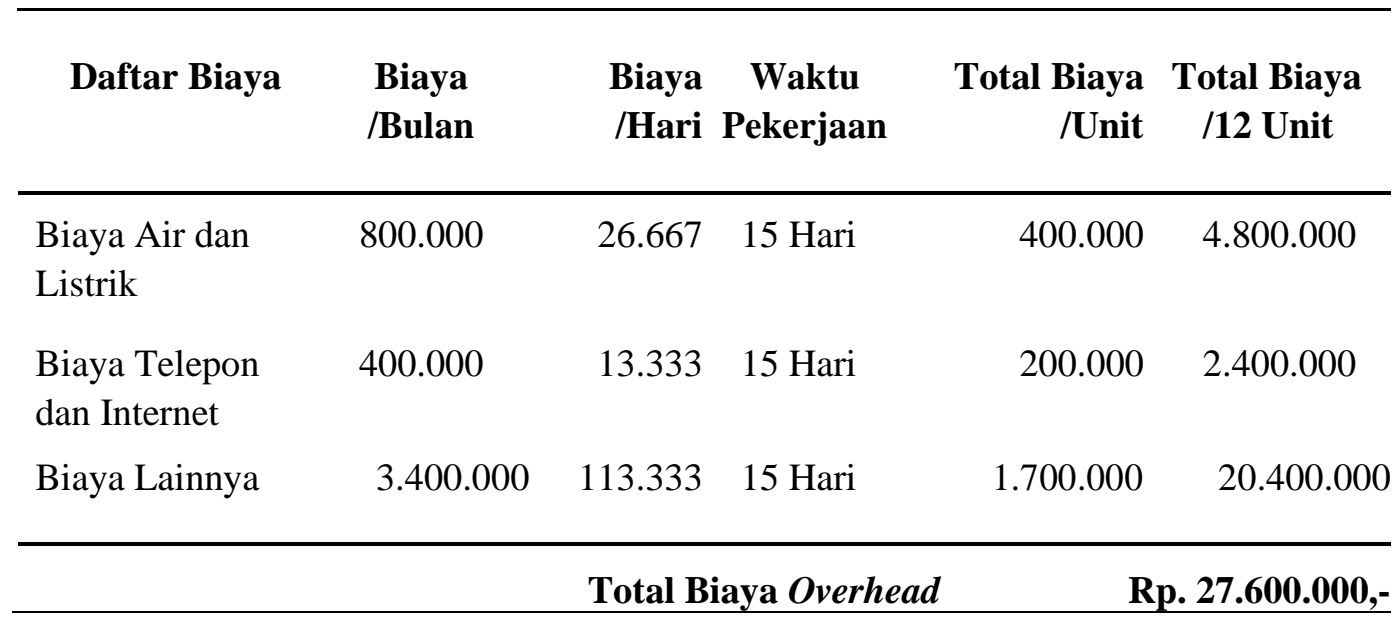

Pada Tabel 4.3. dijelaskan bahwa overhead pada penghitungan perusahaan meliputi biaya air dan listrik, biaya telepon dan internet, serta biaya lainnya, dengan total biaya overhead sebesar Rp. 27.600.000,-.

Tabel 4.4. Penghitungan Harga Pokok Produksi Perusahaan

\begin{tabular}{|c|c|}
\hline Keterangan & $\begin{array}{c}\text { Total Biaya (Interior Mercedes Benz } \\
\text { Sprinter A3) } 12 \text { unit }\end{array}$ \\
\hline Total Biaya Bahan Baku & 1.092.778.291 \\
\hline Total Biaya Tenaga Kerja & 313.200 .000 \\
\hline Total Biaya Overhead & 27.600 .000 \\
\hline Total Harga Pokok Produksi & Rp. 1.433.578.291,- \\
\hline
\end{tabular}

Pada Tabel 4.4. dijelaskan bahwa perhitumgan harga pokok produksi pada penghitungan perusahaan meliputi total biaya bahan baku, total biaya tenaga kerja dan total biaya overhead, dengan total harga pokok produksi sebesar Rp. 1.433.578.291,--

Setelah dilakukan penghitungan harga pokok produksi dengan metode perusahaan, maka dapat dilakukan penghitungan harga jual untuk menentukan margin perusahaan menggunakan harga jual yang telah ditetapkan oleh perusahaan, dengan penghitungan sebagai berikut:

$$
\begin{aligned}
& \text { Harga Jual }=1.433 .578 .291+(1.940 .640 .000-1.433 .478 .291) \times 100 \% \\
& \qquad \begin{aligned}
1.433 .478 .291 & \\
& =1.433 .478 .291+(\mathbf{3 5 , 3 7 \%} \times 1.433 .478 .291) \\
& =\text { Rp. }
\end{aligned}
\end{aligned}
$$




\section{Simulasi Penghitungan HPP Dengan Metode Job Order Costing}

Berikut ini merupakan simulasi komparasi penghitungan HPP dengan Metode Job Order Costing

Tabel 4.5. Biaya Bahan Baku Penghitungan Job Order Costing (Interior Mercedes Benz Sprinter A3) Tender Proyek 12 Unit

\begin{tabular}{lrrr}
\hline \multicolumn{1}{c}{ Nama Bahan } & Qty & Harga @satuan & Total Biaya \\
\hline Biaya Bahan Baku & 12 Unit & 80.064 .858 & 960.778 .291 \\
Biaya Bahan Pendukung & 12 Unit & 11.000 .000 & 132.000 .000 \\
Biaya Perolehan & 12 Unit & 700.000 & 8.400 .000 \\
\hline
\end{tabular}

Total Biaya Bahan Baku

Rp. 1.101.178.291,-

Pada Tabel 4.5. dijelaskan bahwa biaya bahan baku pada penghitungan dengan metode job order costing, meliputi biaya bahan baku, biaya bahan pendukung dan biaya perolehan dengan total biaya bahan baku sebesar Rp. 1.101.178.291,--

Tabel 4.6. Biaya Tenaga Kerja Langsung Penghitungan Job Order Costing (Interior Mercedes Benz Sprinter A3) Tender Proyek 12 Unit

\begin{tabular}{lccccc}
\hline $\begin{array}{c}\text { Jenis } \\
\text { Pekerjaan }\end{array}$ & $\begin{array}{c}\text { Jumlah } \\
\text { Karyawan }\end{array}$ & $\begin{array}{c}\text { Gaji } \\
\text { /Hari }\end{array}$ & $\begin{array}{c}\text { Waktu } \\
\text { Penyelesaian }\end{array}$ & $\begin{array}{c}\text { Total Gaji } \\
\text { /Unit }\end{array}$ & $\begin{array}{l}\text { Total Gaji /12 } \\
\text { Unit }\end{array}$ \\
\hline $\begin{array}{l}\text { Operator } \\
\text { Produksi }\end{array}$ & 7 Orang & 180.000 & 15 Hari & 18.900 .000 & 226.800 .000 \\
Helper & 4 Orang & 120.000 & 15 Hari & 7.200 .000 & 86.400 .000 \\
\hline
\end{tabular}

Total Biaya Tenaga Kerja Rp. 313.200.000,-

Pada Tabel 4.6. dijelaskan bahwa biaya tenaga kerja langsung pada penghitungan dengan metode job order costing, meliputi gaji operator produksi dan gaji helper, dengan total biaya tenaga kerja langsung sebesar Rp. 1.101.178.291,-.

Tabel 4.7. Biaya Overhead Penghitungan Job Order Costing (Interior Mercedes Benz Sprinter A3) Tender Proyek 12 Unit

\begin{tabular}{lrrrcr}
\hline \multicolumn{1}{c}{ Daftar Biaya } & $\begin{array}{r}\text { Biaya } \\
\text { /Bulan }\end{array}$ & $\begin{array}{c}\text { Biaya } \\
\text { /Hari Pekerjaan }\end{array}$ & $\begin{array}{c}\text { Total Biaya } \\
\text { /Unit }\end{array}$ & $\begin{array}{l}\text { Total Biaya } \\
\text { /12 Unit }\end{array}$ \\
\hline $\begin{array}{l}\text { Biaya Air dan Listrik } \\
\text { Biaya Telepon dan }\end{array}$ & 800.000 & 26.667 & 15 Hari & 400.000 & 4.800 .000 \\
$\begin{array}{l}\text { Internet } \\
\text { Biaya Lainnya }\end{array}$ & 400.000 & 13.333 & 15 Hari & 200.000 & 2.400 .000 \\
& 3.400 .000 & 113.333 & 15 Hari & 1.700 .000 & 20.400 .000 \\
\hline
\end{tabular}

Total Biaya Overhead

Rp. 27.600.000,- 
Pada Tabel 4.7. dijelaskan bahwa biaya overhead pada penghitungan dengan metode job order costing, meliputi biaya air dan listrik, biaya telepon dan internet serta biaya lainnya, dengan total biaya overhead sebesar Rp. 1.101.178.291,-.

Tabel 4.8. Biaya Perawatan Peralatan dan Mesin (Interior Mercedes Benz Sprinter A3) Tender Proyek 12 Unit

\begin{tabular}{lccrr}
\hline $\begin{array}{c}\text { Jenis } \\
\text { Barang }\end{array}$ & $\begin{array}{c}\text { Biaya } \\
\text { /Hari }\end{array}$ & $\begin{array}{c}\text { Waktu } \\
\text { Penyelesaian }\end{array}$ & $\begin{array}{c}\text { Total Biaya } \\
\text { Perawatan /Unit }\end{array}$ & $\begin{array}{c}\text { Total Biaya Perawatan } \\
\text { /12 Unit }\end{array}$ \\
\hline Mesin & 8.333 & 15 Hari & 75.000 & 900.000 \\
Peralatan & 5.000 & 15 Hari & 125.000 & 1.500 .000 \\
\hline
\end{tabular}

Total Biaya Perawatan Peralatan dan Mesin $\quad$ Rp. 2.400.000,-

Pada Tabel 4.8. dijelaskan bahwa biaya perawatan peralatan dan mesin pada penghitungan dengan metode job order costing, meliputi biaya perawatan peralatan dan biaya perawatan mesin, dengan total biaya perawatan peralatan dan mesin sebesar Rp. 2.400.000,-.

Tabel 4.9. Biaya Perawatan Kendaraan dan Gedung (Interior Mercedes Benz Sprinter A3) Tender Proyek 12 Unit

\begin{tabular}{|c|c|c|c|c|}
\hline $\begin{array}{c}\text { Jenis } \\
\text { Barang }\end{array}$ & $\begin{array}{l}\text { Biaya } \\
\text { /Hari }\end{array}$ & $\begin{array}{c}\text { Waktu } \\
\text { Penyelesaian }\end{array}$ & $\begin{array}{c}\text { Total Biaya } \\
\text { Perawatan/Unit }\end{array}$ & $\begin{array}{c}\text { Total Biaya Perawatan } \\
\text { /12 Unit }\end{array}$ \\
\hline Kendaraan & 10.000 & 15 Hari & 150.000 & 1.800 .000 \\
\hline Gedung & 6.667 & 15 Hari & 100.000 & 1.200 .000 \\
\hline
\end{tabular}

Total Biaya Perawatan Kendaraan dan Gedung

Rp. 3.000.000,-

Pada Tabel 4.9. dijelaskan bahwa biaya perawatan kendaraan dan gedung pada penghitungan dengan metode job order costing, meliputi biaya perawatan kendaraan dan biaya perawatan gedung, dengan total biaya perawatan kendaraan dan gedung sebesar Rp. 3.000.000,-.

Tabel 4.10. Akumulasi Biaya Penyusutan Peralatan dan Mesin (Interior Mercedes Benz Sprinter A3) Tender Proyek 12 Unit

\begin{tabular}{lcccc}
\hline $\begin{array}{c}\text { Jenis } \\
\text { Barang }\end{array}$ & $\begin{array}{c}\text { Biaya } \\
\text { /Hari }\end{array}$ & $\begin{array}{c}\text { Waktu } \\
\text { Penyelesaian }\end{array}$ & $\begin{array}{c}\text { Total Biaya } \\
\text { Penyusutan /Unit }\end{array}$ & $\begin{array}{c}\text { Total Biaya Penyusutan } \\
\text { /12 Unit }\end{array}$ \\
\hline Mesin & 5.111 & 15 Hari & 76.665 & 919.980 \\
Peralatan & 53.716 & 15 Hari & 805.740 & 9.668 .880 \\
\hline \multicolumn{4}{l}{ Total Biaya Akumulasi Penyusutan Peralatan dan Mesin } & Rp. 10.588.860,- \\
\hline
\end{tabular}

Pada Tabel 4.10. dijelaskan bahwa akumulasi biaya penyusutan peralatan dan mesin pada penghitungan dengan metode job order costing, meliputi akumulasi biaya penyusutan mesin dan akumulasi biaya penyusutan peralatan, dengan total akumulasi biaya penyusutan peralatan dan mesin sebesar Rp. $10.588 .860,-$. 
Tabel 4.11. Akumulasi Biaya Penyusutan Kendaraan dan Gedung (Interior Mercedes Benz Sprinter A3) Tender Proyek 12 Unit

\begin{tabular}{lcccc}
\hline $\begin{array}{c}\text { Jenis } \\
\text { Barang }\end{array}$ & $\begin{array}{c}\text { Biaya } \\
\text { /Hari }\end{array}$ & $\begin{array}{c}\text { Waktu } \\
\text { Penyelesaian }\end{array}$ & $\begin{array}{c}\text { Total Biaya } \\
\text { Penyusutan /Unit }\end{array}$ & $\begin{array}{c}\text { Total Biaya Penyusutan } \\
\text { /12 Unit }\end{array}$ \\
\hline Gedung & 41.352 & 15 Hari & 620.280 & 7.443 .360 \\
Kendaraan & 52.778 & 15 Hari & 791.670 & 9.500 .040 \\
\hline \multicolumn{4}{c}{ Total Biaya Akumulasi Penyusutan Kendaraan dan } \\
\multicolumn{4}{c}{ Gedung } & Rp. 16.943.400,- \\
\hline
\end{tabular}

Pada Tabel 4.11. dijelaskan bahwa akumulasi biaya penyusutan kendaraan dan gedung pada penghitungan dengan metode job order costing, meliputi akumulasi biaya penyusutan gedung dan akumulasi biaya penyusutan kendaraan, dengan total akumulasi biaya penyusutan kendaraan dan gedung sebesar Rp. 16.943.400,-.

Tabel 4.12. Penghitungan Biaya Overhead Sesungguhnya (Interior Mercedes Benz Sprinter A3) Tender Proyek 12 Unit

Daftar Biaya

\begin{tabular}{lr}
\hline \multicolumn{1}{c}{ Daftar Biaya } & Total Biaya /12 Unit \\
\hline Biaya Air dan Listrik & 4.800 .000 \\
Biaya Telepon dan Internet & 2.400 .000 \\
Biaya Lainya & 20.400 .000 \\
Biaya Perawatan Peralatan dan Mesin & 2.400 .000 \\
Biaya Perawatan Kendaraan dan Gedung & 3.000 .000 \\
Akumulasi Penyusutan Peralatan dan Mesin & 10.588 .860 \\
Akumulasi Penyusutan Kendaraan dan Gedung & 16.943 .400 \\
\end{tabular}

Total Biaya Overhead Sesungguhnya
Rp. 60.532.260,-

Pada Tabel 4.12. dijelaskan bahwa penghitungan biaya overhead sesungguhnya pada penghitungan dengan metode job order costing, meliputi biaya air dan listrik, biaya telepon dan internet, biaya lainnya, biaya perawatan peralatan dan mesin, biaya perawatan kendaraan dan gedung, akumulasi penyusutan peralatan dan mesin, serta akumulasi penyusutan kendaraan dan gedung, dengan total biaya overhead sesungguhnya sebesar Rp. 60.532.260,-.

Tabel 4.13. Akumulasi Nilai Residu pada Bahan Baku (Interior Mercedes Benz Sprinter A3) Tender Proyek 12 Unit

\begin{tabular}{lccc}
\hline \multicolumn{1}{c}{ Nama Bahan } & Qty & Harga @satuan & Total Biaya \\
\hline Biaya Bahan Baku & 12 Unit & 600.500 & 7.206 .000 \\
Biaya Bahan Pendukung & 12 Unit & 123.000 & 1.476 .000 \\
\hline
\end{tabular}

Total Biaya Bahan Baku

Rp. 8.682.000,- 
Pada Tabel 4.13. dijelaskan bahwa akumulasi nilai residu bahan baku pada penghitungan dengan metode job order costing, meliputi akumulasi biaya bahan baku dan biaya bahan pendukung, dengan total akumulasi nilai residu pada bahan baku sebesar Rp. 8.682.000,--

Tabel 4.14. Penghitungan Harga Pokok Produksi Dengan Metode Job Order Costing

\begin{tabular}{lr}
\hline \multicolumn{1}{c}{ Daftar Biaya } & Total Biaya /12 Unit \\
\hline Biaya Bahan Baku & 1.101 .178 .291 \\
Biaya Tenaga Kerja Langsung & 313.200 .000 \\
Biaya Overhead Sesungguhnya & 60.532 .260 \\
\hline \multicolumn{1}{c}{ Total } & Rp. 1.474.910.551 \\
Akumulasi Nilai Residu pada Bahan Baku & 8.682 .000 \\
\hline \multicolumn{2}{c}{ Total Harga Pokok Produksi } \\
\hline
\end{tabular}

Pada Tabel 4.13. dijelaskan bahwa harga pokok produksi pada penghitungan dengan metode job order costing, meliputi biaya bahan baku, biaya tenaga kerja langsung dan biaya overhead sesungguhnya, dengan total sebesar Rp. 1.474.910.551,-, kemudian dikurangi dengan akumulasi nilai residu pada bahan baku sebesar Rp. 8.682.000,-. Total harga pokok produksi dengan metode job order costing yaitu sebesar Rp. 1.466.228.551,--.

Setelah dilakukan penghitungan harga pokok produksi dengan metode job order costing, maka dapat dilakukan penghitungan harga jual untuk menentu-kan margin perusahaan menggunakan harga jual yang telah ditetapkan oleh perusahaan, dengan penghitungan sebagai berikut:

$$
\begin{aligned}
\text { Harga Jual }= & 1.466 .228 .551+\left(\frac{1.940 .640 .000-1.466 .228 .551) \times 100 \%}{1.466 .228 .551}\right. \\
& \quad x 1.466 .228 .551 \\
= & 1.466 .228 .551+(\mathbf{3 2 , 3 6 \%} \times 1.466 .228 .551) \\
= & \text { Rp. } 1.940 .640 .000,-
\end{aligned}
$$

\section{Pembahasan}

Setelah dilakukan simulasi penghitungan, maka dapat di ambil analisa perbedaan penghitungan harga pokok produksi yang dilakukan perusahaan dengan penghitungan harga pokok produksi dengan metode job order costing. 
Tabel 4.15. Perbandingan Penghitungan Harga Pokok Produksi Perusahaan dengan Metode Job Order Costing

\begin{tabular}{|c|c|c|c|c|}
\hline \multirow{2}{*}{ Deskripsi } & \multicolumn{2}{|c|}{ Perhitungan Harga Pokok Produksi } & \multirow{2}{*}{ Selisih } & \multirow{2}{*}{ Keterangan } \\
\hline & $\begin{array}{c}\text { Perusahaan } \\
\text { Interior } 12 \text { Unit }\end{array}$ & $\begin{array}{l}\text { Job Order Costing } \\
\text { Interior } 12 \text { Unit }\end{array}$ & & \\
\hline Biaya Bahan Baku & 1.092 .778 .291 & 1.101.178.291 & 8.400 .000 & $\begin{array}{l}\text { Perusahaan tidak } \\
\text { memasukkan } \\
\text { biaya perolehan } \\
\text { bahan baku }\end{array}$ \\
\hline $\begin{array}{l}\text { Akumulasi Nilai } \\
\text { Residu pada } \\
\text { Bahan Baku }\end{array}$ & & $(8.682 .000)$ & $(8.682 .000)$ & $\begin{array}{l}\text { Perusahaan tidak } \\
\text { mengurangi } \\
\text { akumulasi nilai } \\
\text { residu pada bahan } \\
\text { baku }\end{array}$ \\
\hline $\begin{array}{l}\text { Biaya Tenaga } \\
\text { Kerja Langsung }\end{array}$ & 313.200 .000 & 313.200 .000 & - & - \\
\hline Biaya Overhead & 27.600 .000 & 60.532 .260 & 32.932 .260 & $\begin{array}{l}\text { Perusahaan tidak } \\
\text { memasukkan: }\end{array}$ \\
\hline & & & & $\begin{array}{l}\text { 1. Biaya perawatan } \\
\text { peralatan, mesin, } \\
\text { kendaraan dan } \\
\text { gedung. } \\
\text { 2. Biaya akumulasi } \\
\text { penyusutan } \\
\text { peralatan, mesin, } \\
\text { kendaraan dan } \\
\text { gedung. }\end{array}$ \\
\hline Total HPP & 1.433.578.291 & 1.466 .228 .551 & 32.650 .260 & \\
\hline
\end{tabular}

Berdasarkan Tabel 4.15. dapat diketahui bahwa terdapat perbedaan nilai dan hasil penghitungan harga pokok pesanan antara penghitungan PT Oto Media Kreasi dengan penghitungan harga pokok pesanan metode Job Order Costing.

Penghitungan harga pokok produksi dengan menggunakan metode Job Order Costing memiliki nilai lebih tinggi dibandingkan dengan penghitungan meng-gunakan metode perusahaan. Hasil penghitungan menurut PT Oto Media Kreasi-untuk 12 Unit Interior Mercedes Benz Sprinter A3 sebesar Rp.1.433.578.291. Sedangkan menurut hasil analisis dengan metode Job Order Costing untuk total 12 Unit Interior Mercedes Benz Sprinter A3 yaitu sebesar Rp.1.466.228.551. Terdapat selisih penghitungan harga pokok pesanan sebesar Rp.32.650.260.

Penghitungan harga jual dengan menggunakan metode Job Order Costing memiliki nilai persentase margin lebih kecil dibandingkan dengan penghitungan menggunakan metode perusahaan. Hasil penghitungan menurut PT Oto Media Kreasi untuk total 12 Unit Interior Mercedes Benz Sprinter A3 sebesar 35,37\%. Sedangkan menurut hasil analisis dengan metode Job Order Costing untuk 12 Unit Interior Mercedes Benz Sprinter A3 yaitu sebesar 32,36\%. Terdapat selisih penghitungan harga pokok pesanan sebesar 3,01\% dalam penentuan harga jual.

Perbedaan selisih dalam penghitungan harga pokok produksi berdasarkan pesanan sebesar Rp.32.650.260 dan selisih pada perolehan margin perusahaan sebesar 3,01\% terjadi karena adanya selisih pada penghitungan biaya bahan baku sebesar Rp.8.400.000 dari penghitungan biaya bahan baku yang dilakukan perusahaan sebesar Rp.1.092.778.291 dengan metode job order costing sebesar Rp.1.101.178.291. Perusahaan hanya membebankan biaya bahan baku berupa biaya bahan baku dan biaya bahan pendukung 
(subcond). Sedangkan menurut metode Job Order Costing seharusnya perusahaan melakukan penghitungan secara terperinci, apa saja yang masuk ke dalam biaya bahan baku akan mempengaruhi harga dari produk yang di buat seperti biaya bahan baku, biaya bahan pendukung dan biaya perolehan barang.

Terdapat selisih pada penghitungan dalam metode Job Order Costing yaitu akumulasi nilai residu pada bahan baku sebesar Rp. 8.682.000 yang mengurangi dari total biaya bahan baku. Perusahaan tidak mengurangi akumulasi nilai residu pada bahan baku. Pada penghitungan biaya tenaga kerja yang dilakukan perusahaan sudah sesuai dengan metode Job Order Costing yaitu sebesar Rp.313.200.000.

Sedangkan pada penghitungan biaya overhead terdapat selisih sebesar Rp.32.932.260 dari penghitungan yang dilakukan oleh perusahaan sebesar Rp.27.600.000 dan penghitungan dengan metode $J o b$ Order Costing sebesar Rp.60.532.260. Perusahaan hanya membebankan biaya overhead berupa biaya air dan listrik, biaya telepon dan internet dan biaya lainnya. Sedangkan menurut metode Job Order Costing seharusnya perusahaan melakukan penghitungan secara terperinci, apa saja yang masuk ke dalam biaya overhead akan mempengaruhi harga dari produk yang di buat seperti biaya air dan listrik, biaya telepon dan internet, biaya lainnya, biaya perawatan peralatan dan mesin, biaya perawatan kendaraan dan gedung, biaya akumulasi penyusutan peralatan dan mesin, serta biaya akumulasi penyusutan kendaraan dan gedung.

Dari temuan penelitian dan hasil penelitian yang telah dilakukan, terlihat bahwa perusahaan dalam melakukan penghitungan harga pokok produksi meng-gunakan metode yang sederhana, belum menggunakan metode job order costing didalamnya, dan dalam menentukan harga untuk satuan produk yang di pesan hanya berdasarkan taksiran, sehingga terdapat banyak perbedaan jika dibanding-kan dengan metode job order costing.

Dalam hal ini terlihat bahwa peranan metode job order costing sebagai salah satu metode penghitungan harga pokok produksi berperan penting untuk meningkat-kan keefektifan sebuah perusahaan dalam menentukan biaya-biaya yang dibutuh-kan selama proses produksi barang yang diinginkan oleh konsumen berdasarkan pesanan yang diinginkan. Dan metode ini diharapkan juga dapat digunakan untuk menghitung harga pokok produksi untuk setiap produk yang di buat, sehingga dapat menentukan harga jual yang efektif dan menghasilkan keuntungan sesuai dengan yang diharapkan.

\section{SIMPULAN DAN SARAN}

\section{Simpulan}

Berdasarkan hasil penelitian yang telah dilakukan, maka dapat ditarik kesimpulan bahwa penghitungan harga pokok produksi dengan metode job order costing pada PT Oto Media Kreasi, adalah sebagai berikut:

1. Dalam penghitungan harga pokok produksi PT Oto Media Kreasi masih menggunakan penghitungan yang sederhana, hanya melakukan penghitungan biaya bahan baku yaitu Rp.1.092.778.291, biaya tenaga kerja langsung Rp.313.200.000, dan biaya overhead Rp.27.600.000. Total penghitungan harga pokok produksi perusahaan sebesar Rp.1.433.578.291, dengan persentase margin 35,37\% dari harga jual Rp.1.940.640.000.

2. Sedangkan dalam penghitungan harga pokok produksi menggunakan metode job order costing pada penghitungan biaya bahan baku Rp.1.101.178.291, akumulasi nilai residu pada bahan baku Rp.8.682.000, biaya tenaga kerja langsung Rp.313.200.000, dan biaya overhead Rp.60.532.260. Total penghitungan harga pokok produksi dengan metode job order costing sebesar Rp.1.466.228.551, dengan persentase margin 32,36\% dari harga jual Rp.1.940.640.000.

3. Dari hasil penelitian yang telah dilakukan dapat diketahui bahwa perusahaan belum melakukan penghitungan harga pokok produksi dengan metode job order costing, penghitungan harga pokok produksi yang dilakukan perusahaan hanya-dengan menaksir seluruh biaya-biaya yang dibutuhkan untuk memproduksi suatu produk, sehingga biaya-biaya tidak diklasifikasikan secara tepat dan perhitungan yang dilakukan cukup sederhana, sehingga sulit untuk menentukan harga jual yang tepat untuk suatu produk yang di pesan. 


\section{Saran}

Berdasarkan hasil penelitian yang telah dilakukan dengan perbandingan antara penghitungan menurut perusahaan dengan penghitungan menurut metode job order costing, maka dapat diberikan saran sebagai berikut:

1. Perbedaan yang terjadi dalam penghitungan harga pokok produksi menurut perusahaan dengan menurut metode job order costing harus menjadi perhatian khusus dari pemilik perusahaan dalam menentukan harga pokok produksi. Tindakan yang harus di ambil adalah dengan melakukan koreksi pada perhitungan harga pokok produksi, perusahaan harus sesuai dengan metode job order costing dengan menghitung dan mengidentifikasikan biaya bahan baku, biaya tenaga kerja dan biaya overhead.

2. Berdasarkan hasil analisis apabila perusahaan dalam menetapkan harga pokok produksi menggunakan metode job order costing, sehingga penghitungan harga pokok produksi menjadi lebih akurat karena semua biaya dikelompokkan dalam biaya produksi yang di hitung secara terperinci.

3. Dengan adanya penghitungan untuk biaya perawatan dan biaya penyusutan, perusahaan akan mengetahui umur ekonomis sehingga dapat di rawat dan di ganti jika peralatan dan mesin sudah habis masa pakai.

4. Adanya usulan penggunaan metode job order costing diharapkan agar pemilik perusahaan bisa menerapkan penghitungan harga pokok produksi tersebut supaya perusahaan dapat menentukan harga pokok produksi dalam penentuan harga jual secara lebih tepat, dengan begitu pemilik dapat mengetahui keseluruhan biaya produksi pesanannya dan juga dapat mengetahui perolehan margin yang sebenarnya.

\section{DAFTAR PUSTAKA}

Agus Purwaji, Wibowo, Sabarudin Muslim. Akuntansi Biaya (Edisi 2). Salemba Empat, Jakarta.

Aningsih, R. F., \& Diyani, L. A. 2018. Penghitungan Harga Pokok Produksi Wacana Menggunakan Metode Tradisional Costing dan Activity Based Costing. Jurnal Online Insan Akuntan.

Bustami, B dan Nurlela. 2013. Akuntansi Biaya (Edisi 4). Mitra Wacana Media, Jakarta.

Carter WK. 2015. Cost Accounting (Edisi 14). Terkrista. Salemba Empat, Jakarta. Dewi Y, Tripaupi LE, Zukhri A. 2017. Analisis Metode Job Order Costing Dalam

Menentukan Harga Pokok Produksi Pada Srada Lamp's Di Gianyar. Universitas Pendidikan Ganesa. EJournal Pendidikan Ekonomi. Vol. 10, No. 2. 2017.

Fardhani N, Morasa J, Wangkar A. Evaluasi Penerapan Job Order Costing Method Dalam Penetuan Harga Pokok Produksi Pada CV. Visual Komunika Mandiri. Jurnal Berkala Ilmiah Efisiensi, Volume 16 No. 04 Tahun 2016.

Faridah E, Kuswara T. 2017. Pengaruh Harga Pokok Produksi Terhadap Harga Jual. Pada Perusahaan Peleburan Alumunium Cap Elang Mas. Jurnal Wawasan dan Riset Akuntansi. Vol. 5 No. 1, 2017.

Hansen dan Mowen. 2009. Akuntansi Manajerial (Edisi 8). Salemba Empat, Jakarta.

Hermanto B. 2016. Penghitungan Harga pokok Pesanan (Job Order Costing) Produk (BRKT Number Plate K56) Pada PT Rachmat Perdana Adhimental. Politeknik Jakarta LP3I. Jurnal Ekonomi WIGA. Vol. 6 No. 01.

Latief A. 2017. Metode Cost Plus Pricing Dengan Pendekatan Full Costing Mampu Menentukan Harga Jual (Studi Kasus Pada CV Karya Dharma). Jurnal Bisnis dan Kewiraushaan. Vol. 6 No. 2. 2017.

Mulyadi. 2018. Akuntansi Biaya. Akuntansi Biaya. (Edisi 5). Cetakan kelimabelas.

UPP-STIM YKPN, Yogyakarta.

Permatasari, Z. 2011. Panduan Praktikum Akuntansi Biaya. Universitas Gunadarma, Depok.

Setiadi P, David P, Treesje R. 2014. Penghitungan Harga Pokok Produksi Dalam Penentuan Harga Jual Pada CV Minahasa Mantap Perkasa. Universitas Sam Ratulangi. Jurnal Efisiensi Berkala Ilmiah. Vol. 14 No. 2. 
Siregar, Baldric, Suripto, Bambang. 2013. Akuntansi Biaya (Edisi 1). Salemba Empat, Jakarta. Sujarweni V. Wiratna. 2015. Akuntansi Manajemen Teori dan Aplikasi. Pustaka Baru Press, Yogyakarta.

Sugiyono. 2014. Metode Penelitian Pendidikan Pendekatan Kuantitatif, Kualitatif, dan R\&D. Alfabeta, Bandung.

Widyastuti I, Mita D. 2018. Akuntansi Penghitungan Harga Pokok Penjualan Dengan Metode Pesanan Untuk Menentukan Harga Jual. Jurnal Moneter. Vol. 5 No.1.

Windriasari M. 2017 Analisis Penerapan Metode Activity Based Costing dalam Penentuan Harga Pokok Produksi Roti pada UD. Ganysha Kediri. Simki-Economic, Vol. 01 No. 01.

Yuliyanti Y, Saputra RS. 2017. Analisis Harga Pokok Produksi Roti Berdasarkan Metode Full Costing dan Variable Costing. Jurnal Online Insan Akuntan. Vol. 02 No. 02.

Zulkarnain MZ, Widodo. 2016. Penghitungan Harga Pokok Produksi Dengan Metode Job Order Costing Pada PT ABC. Jurnal Akuntansi Bisnis. Vol. 03 No 01 